\title{
わが国の経済情勢と味噌, しょう油業界の動向
}

わが国の経済は物財生産中心の工業化社会から知識産業社会へ移行し つつあり, また, 円切り上げによって産業構造の変化は加速されようと しています。このような経営環境の変化に対して中堅企業の役割が新た に注目を惹いておりますが, 筆者は, 味噌, しょう油業界においても, 一つの重要な発展方向として, その活躍を期待しております。なお本稿 は第 57 回醸造調味食品講習会の報告に基づいて述べられています。

東京農業大学

棣川荷

\section{1. ドル・ショックにどう対処すべきか}

ドル・ショックが日本経済に与えた影響は, いささか 誇張して申せば, 戦後最大でありましよう。これをきっ かけに, わが国の外国為替相場は, IMF の略称で知ら れている国際通貨制度で定められている為替相場の固定 比率制を離れて変動相場制に移行して和ります。この変 動相場制は，戦前の金本位制度の下では，至極当り前の ことであって変動の波に乗ってしこたま儲けたり大損も したりしたものでした。ところが，戦後になりますと昭 和 24 年に円の対外価值は， 1 ドル 360 円に固定されて 現在にいたったので，これが変動するとなると不馴れの ため戸惑うのも無理からぬことでありましよう。IMF に代る新たな国際通貨制度は，真剣に，そしてまたなる ベく早期に確立されることが望ましいのですが，この問 題の検討は別の機会にゆずるとしまして, さしあたって は円の切り上げをどの程度のところに落着かせるか, 米 国を筆頭に諸外国はもらろんのこと, わが実業界でも政 府の決断が待たれていることに注目したいと思いるす。

円の切り上げが 10\%か，または 15\% になるか予断 を許しませんが，円が切り上げられることは，ほぼ確実 であり，その実施は年内でありましよう。戦後の日本経 済が, 円の対外価值 1 ドル=360 円を軸にして形成され てきたといらことには，重大な意義があります。固定さ れた当初は，円の力が弱いため，国民は必至になって日 本経済の再建に全精力を傾注せざるを得なかったので した。いわば円安すが経済再建の鞭となったのでした。 周知のごとく資源の負弱な日本は, 原料等を海外に求め なければならないので, 貿易立国は明治維新以来の基本 国策の一つに数えられています。円安すから脱却の道は,

第 66 巻 第 12 号
輸出競争力の強い商品を生産しうるような日本産業を育 成することに求められたのは理の当然でありましよう。 戦後の手厚い保護貿易は, この目的にとって不可欠でし た。これなくしては, わが国の自動車産業や家電産業, さらには基幹産業である鉄鋼業などは，今日みられるよ らな隆盛を誇り得なかっただあろうことは間違いありま せん。

幸いにも日本経済の再建は，世界の驚異の的となるほ ぞまで成功しました。その一つの証查は, 円高か, つま り円の対外価值が強くなったことにらかがえます。とこ ろが過ぎたるは，な特及ばざるがごとし，で円が日本経 済の実力以下に固定されてしまったところに，今日の円 切り上げ問題の発生原因が伏在していたのです。ドル・ ショックは，その強烈な顕在化にほかなりません。

円の切り上げで米国の言いなりになることは，日米の 通貨戦争でわが国の敗北を意味すると見ている向きがあ ります。もちろん，言いなりになるような自主性のない ことでは困りますが，この際は経済学の教えるところに 耳を傾け，日本の国際政治力も勘案して慎重な判断を下 しませんと第二次世界大戦の愚を繰り返すことにもなり かねません。経済学は自然界には自然法則が見出される ように経済界もまた経済の論理によって支配されている ことをわれわれに教えてい穒す。われわれは, 経済の論 理にさからって行動することもでさますが，その結果は 何等かの形で罰を受けることを覚悟しなければなります まい。放慢経営が倒産によって罰せられるように。円の 切り上げは，その実施時期や切り上げ幅等については微 妙な問題がからんでいますが，原則的には経済の論理に 叶っていることを多くの経済学者も認めて拉ります。わ が国の国際政治力については, 専門外なので積極的な発 
言は慎しみたいと思いますが，ぞうしても言及して和か なければならない点もありますので例示的に所見を述べ るす。わが国の鉄鋼業のコストは米国にくらべて 70\% です。かって量質共に世界一を誇った米国の鉄鋼業が, どうしてコスト高になってしまったか，その理由として 恃，骨の折孔る技術革新の導入を㤐って生産性の向上飞 努力しなかったこと，また米国民は開拓者精神を失って， いたずらに貢上げ闘争に明け暮れしていたことなぞが指 摘されています。そうした怠惰を棚上げして，必死の努 力で築き上げた日本経済に対して，円を切り上げろ，だ けならまだしる $10 \%$ の輸入課徴金を強制するにいたって 忙語同断,と力みたくもなります。しかも,このたかま る感情は, 確固とした経済論理で裏付けることもできる のです。世界経済に和いて，ドル安すは米国経済の相対 的地位の低下を, また円高かは日本経済の相対的地位の 上昇といら客観的事実を指摘して拈きむしょう。しかし， 米国の側にも有力な経済の論理が与兄られています。日 本の国際収支の黒字が恒常化しつつあることは, 国際的 不均衡の一端を担っていることになります。日本の黒字 性国の赤字に対応するのですから，こらした不均衡が 永続してよい筈はありません。国際紛争を裁定する上位 者として国内に括ける個人間の争いを裁く国家のような ものは, まだ存在しないのですから，わが国としては国 際政治力の末熟な現段階では, いたずらに我（が）を通 してわが方に不利な紛争の種を蒔くことは厳に慎むべき ではないでしょうか。この際は, 多少の輸出は犠牲にし ても一歩退いて国内の充実, たとえば公害やその他の都 市問題に鋭くあらわれている高度成長のひずみを是正す るために不足している社会資本や国民福祉の充実に邁進 する方が国家百年の大計に叶っていると思います。

\section{2. 経済情勢の把握と予測}

ドル・ショックは, 円の切り上げとそれと伴ら日本産 業の再編成によって吸収されるわけですが，論点を当面 の醇造業界に絞りますならば，大した影響はないという のが大まかな結論となりましよう。円切り上げによりま して輸出は,やりにくくなりましようが, 䤑造業界は輸 出重点産業に属しては招りませんから問題になりませ ん。キッコーマン醬油のように対米輸出 (年間輸出 7 億 円の $80 \%$ が対米輸出）には見るべきるのがありますが, 課徴金は值上げでカバーしうる実力を持っていますし， 若干の為替差損は, 円の切り上げによる輸入価格の下落 が見込まれるので脱脂大豆の輸入面のメリットで埋める こともできましょう。アメリカ大豆の輸入価格がどの程 度引下け゚られるか, 見通しは困難です。相場変動の激し い商品ですし, 円切り上げの效果は輸入業者の中間マー
ジンを肥やすのみで, 味噌業界にまで均霑しないのでは ないかと見る向きも多いようです。

円切り上げの当面の効果は, 以上の上らであります が，その間接的または長期的効果を考虑にいれますと， 事態は一変して容易ならぬ問題, それは国際経済の新情 勢檤合するような日本経済を再建するという課題に直 面します。そして，いやしくも貿易がわが国の生命線で ある以上，国際経済へ適合の道を回避することは許され ません。日本経済の再建と申しましたが，それは単独に 経済界のみを切り離しての問題ではなく, 政治・外交・ 文化をワン・セットとして全般にわたる再検討が要請さ れているのです。しかし，ここでは全般的な背景を踏ま えた上で視野を, 円切り上げに伴う産業調整に限定しま すが，そのために，最近の経済情勢の診断と予測を行な らことによってとこに至るレールを敷いて牤きたいと思 います。

業界人にとりましては, 経済情勢の変化は多年の経験 に基いて肌で感じとって拈り, また, 企業の経営計画に 生かすことに馴れて物りますから, 今さら, 経済情勢と は何か，とひらきな特って問うには当らないかも知孔ま せんが，各自の鋭い直感的判断とは別個に客観的な判断 材料として経済情勢を把握して拉くことは，前者を正し く生かす上に执いて子必要不可欠と思います。経済情勢 と一ロに申しても, その内容は複雑多岥です。とこから なるべく単純に操作しうる指標 (indicator) を見出して くるのがコッですが，それはあたかも德天皇が高殿に 登られ，民家から立ちのぼる煙をごらんになって民生の 安否を判断されたことや，下ってはカーネギーが工場の 煙突の煙の立ち工合によって産業界の浮沈を判断した手 法に相通ずるものがあります。今日では, 日本人を得意 にさせている経済指標の最たるものは GNP でしょう。 これによってわが国は自由国家群の第 2 位に位置付けら れているのですから。経済の規模では第 2 位ですが, 生 活水準を示す 1 人当り国民所得 $(\mathrm{Y} / \mathrm{N})$ では十指にも数 号れていないことは周知のと物りです。このような相

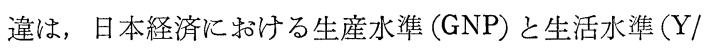
N) の予盾として，つとに指摘されても扔ります。

経済指標の選び方によって, 日本経済のいろいろな姿 が浮び上ってくるわけですが，時々刻々に变る経済情勢 の変化を把握するというばあい，その中心的役割を果す のは景気指標でありましょう。景気とは, 日本経済全体 としての経済活動情況が, 旺盛と沈滞を交互に繰り返す ことをいらので, 景気指標として物価を選んでグラフを 画くならば，波動形として記述することができます。か くて経済情勢は, 景気变動としてマク口的に把握される のですが，それが直ちに醸造業界や所属企業の動向に一 
致するとは限らないところに厄介な問題が潜んでいま す。マクロー（一国経済全体）とミクロ（個別企業）は ぞのように関連し合うかについては学問上でも問題にな っていますが，まだ事例蒐集の域を出ず，理論化には程 遠いといらのが現状です。な扮, 醽造業界は一つの産業 として，マクロとミクロの中間レベルに位置付けられま すことを蛇足ながら申し添えて物さすす。

経済情勢の診断には, 景気に鋭敏な指標, すなわち景 気指標を選ぶのですが，それには上述の物価，生産高， 雇用など手軽杽できる指標が沢山あります。そのな かから一つを選び, 単一指標で景気（二経済情勢）を診 断し, 進んでは予測も行ならといらことは, もっとも手 取りばやい方法であります。しかし, 物価と景気が常に 一致関係にあれば文句ないのですが, 物価安定, 生産上 昇の数量景気（通例の価格景気に対して）といわれるば あいには，影気の実体的な動きを見失ってしまいます。 そこでくただ一つの指標に頼るな〉といった景気観測上 の実践ルールが与兄られることにもなるわけです。安心 して景気ないし経済情勢の診断と予測を実行するために は, いくつかの指標を用意して比較検討しなければなり ません。さらに, 景気指標のらちには, 景気の動きに一 致するものばかりあるのではなくて, これに先行し, あ るいは遅れるのもあることが見出されています。そして 景気指標間の先行・遅行関係を活用して景気予測に効果 をあげている一例としては景気動向指数（経企庁）があ りますが，景気の一般的な診断と予測として利用するの に便利です。これを規準として，業界や個別企業に和け る生産, 出荷などの時系列統計を比較対照するならば, 今までに気付かなかった事実を発見することができなし ょうし，使用する指標の数を最少限度にとどめるように して, 必要に応じて増減するといった気楽な気持で発足 することです。ともあれ，自分で景気の診断や予測を実 行することによって, 他から与えられる情報も適切に取 捨選択が可能となるのでして，そらでなければ，いろい ろの情報結果に迷わされてしまうことにもなりか㸚ませ え。

戦後の景気過程は第 1 表に示されています。

第 1 表 戦後の景気循環

\begin{tabular}{|c|c|c|c|c|c|c|}
\hline & \multirow{2}{*}{ 谷 } & \multirow{2}{*}{ 山 } & \multirow{2}{*}{ 谷 } & \multicolumn{2}{|c|}{ 期 } & 間 \\
\hline & & & & 拡 張 & 収 縮 & 全循環 \\
\hline $\begin{array}{l}\text { 第 } 1 \text { 循環 } \\
\text { 第 } 2 \text { 循環 } \\
\text { 第 } 3 \text { 循環 } \\
\text { 第 } 4 \text { 循環 } \\
\text { 第 } 5 \text { 循環 } \\
\text { 第 } 6 \text { 循環 }\end{array}$ & $\begin{array}{l}26 \text { 年 } 10 \text { 月 } \\
29 \text { 年11月 } \\
33 \text { 年 } 6 \text { 月 } \\
37 \text { 年10月 } \\
40 \text { 年10月 }\end{array}$ & $\begin{array}{l}26 \text { 年 } 6 \text { 月 } \\
29 \text { 年 } 1 \text { 月 } \\
32 \text { 年 } 6 \text { 月 } \\
36 \text { 年 } 12 \text { 月 } \\
39 \text { 年 } 10 \text { 月 } \\
45 \text { 年 }\end{array}$ & $\begin{array}{l}26 \text { 年 } 10 \text { 月 } \\
29 \text { 年 } 11 \text { 月 } \\
33 \text { 年 } 6 \text { 月 } \\
37 \text { 年 } 10 \text { 月 } \\
40 \text { 年 } 10 \text { 月 }\end{array}$ & $\begin{array}{l}27 \text { か月 } \\
31 \text { か月 } \\
42 \text { か } \\
24 か 月 ~\end{array}$ & $\left|\begin{array}{c}(4 \text { か月 }) \\
10 \text { か月 } \\
12 \text { 加 } \\
10 \text { 另月 } \\
12 \text { 月 }\end{array}\right|$ & $\begin{array}{l}37 \text { か月 } \\
43 \text { か月 } \\
52 \text { か月 } \\
36 \text { か月 }\end{array}$ \\
\hline 第 6 循環 & & & & 31か月 & 11か月 & 42 か月 \\
\hline
\end{tabular}

第 66 巻 第 12 号
第 6 循環では, 循環開始の谷は 40 年 10 月ですが, 山は末確定で推定としては 45 年の 9 月頃とされていま す。な拈, 到着の谷は本年の 6 7 月頃とみられていま したが, 例の 8 月 16 日のドル・ショックで景気の回復 は延期され, 目下の日本経済は引続芑不況局面低低迷し て和ります。しからば，いつ頃になったら日本経済は不 況から脱却するか，その予測は各種の景気観測機関で行 なわれていますが，ここでは日経の経済研究センターの 分を揭げて技さます。円の切り上げを $14.29 \%$ と仮定し ますと，本年の実質成長率は $3.8 \%$ ，明 47 年は $10.1 \%$ で, 円不況は短期間に集中するので景気は明年の $4 \sim 6$ 月期に回復に向う。そして，マクロ面では景気回復に向 うもののミクロ面では企業格差が目立つようになる。る ちろん, このような影気の早期回復は政府の行なら景気 浮揚政策である所得減税，公共投資の拡大，公定歩合の 第 5 次引下げが適時に行なわれることを前提としてのこ とであります。

\section{3. 景気循環・経済成長・構造変化の関連}

経済成長については触れませんでしたが, 成長率の国 際比較は第 2 表のと括りです。日本経済の成長率予測 は, ドル・ショック以 来, 円の切り上げによ る基本的条件の変化も 織り込まなければなら ないので, 従来より低 めに，たとえば 10\% を $7.8 \%$ といらように 改訂されることになり ましよう。

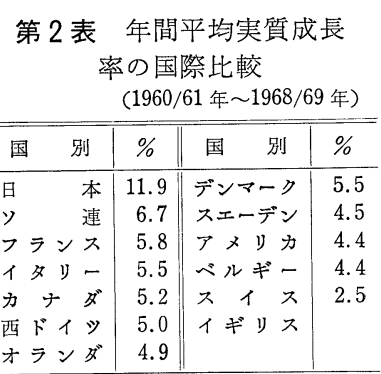

景気変動は, 右上り

の単調増加曲線で示される成長率の上下をめぐっての循 環というのが現実の姿で，これを循環的成長と呼んでお ります。経済の成長は, 人口や資本の単なる量的増加に よって，もたらされもしますが多くのばあい，質的変化 が必ずといってもよい注ど付㐰わります。その原動力 は，主として技術革新でありますが，その効果は経済成 長湾伴う産業構造の変化として把握することができすす。 さらに, 不況下の通貨調整 (円切り上げ)などによって, 産業構造の変化は加速されると同時に国際競争力の強い 産業や企業は発展しますが, 弱いばあいは自然淘汰の悲 運にさらされるでしょう。自律的に自から進んでは適応 しえない産業や企業に対しては経済政策の面より促進策 が講じられましよう。これが円の切り上げに伴ら産業調 整といわれるものです。

景気変動は，波動型の循環運動ですが，その量的変化 
の基底には，経済成長ならびに産業構造の質的変化があ り，三者は不可分の一体を構成しています。特に日本経 済のように成長率の高いばあいには, 各景気循環の質的 変化, 別言すれば一つ一つの循環の個性に注意を払う必 要があるわけでして，円の切り上げが産業構造にどのよ らな変化をもたらすが関心が高まっているのは当然の ことといえましよう。

景気指標は, 経済活動ないし経済情勢の量的変化しか 表示しえず，その間に生じつつある質的変化の側面につ いては，これを別途求めなければなりません。また， 景気循環の軸をなしている経済成長についても同じこと がい党ます。したがって, 経済情勢変化の量ならびに質 の両側面を同時に示すような指標の考案は, 将来になた ざるをえないというのが現状です。もちろん，工手間を いとわぬならば，経済情勢変化の指標としての景気循環 や経済成長の基底に生じつつある経済の質的变化, 即ち 経済構造変化を示すデータは豊富に存在していますので， 経済情勢変化の量的側面を質的側面をるって補完する道 は開かれているわけです。

経済情勢变化の指標は, 経済統計のらちの時系列から 求められますが，それは季節変動・不規則変動・景気变 動・趨勢変動（トレンド）の成分を含むものとみられて います。季節変動を除去し, 今回のドル・ショックのよ らな不規則変動の発生していない時期を選ぶなら, 時系 列は主として景気循環と経済成長の二成分から構成され ているとみなすことができるわけです。戦争や大がかり なストライキなども不規則変動要因として代表的なもの ですが, 不規則変動の作用が強力なときは, 経済の正常 状態でみられる景気循環や経済成長のパターンは, 大幅 そゆがめられますから経済情勢の予測にあたっては，こ のことを考慮にいれて特くべきです。

\section{4. 味噌, しょう油業界の動向}

味噌, しょう油は, 清酒と共にわが国古来からの飲食 物で晾り，伝統産業として長い歴史を誇っています。そ の間に品質は洗練され, 改良の余地は少なく, 時代が変 ったからといってやたらに品質の内容をいじくりまわし

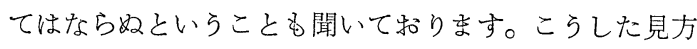
飞一面の真理の㔖ることは認めますが，伝統食品とい光 ぞも，これを最終完成品と考光るならば問題が残りまし よう。むしろ伝統食品であればこそ “温故知新” の精神 をもって古きよさを新時代に生かすべきでありましよ ら。故（ふる）きを温（たず）ねて新しきを知れば以て 師たるべし，とは論語の為政篇にある有名な語句です が, 伝統食品を新しい時代に生かしらる人物こそ伝統産 業のリーダーたりらる筈で, そのような人物が待望され
ているわけです。伝統を現代に生かすといらことは，容 易なことではなく，骨の折れる革新の一つに数劣あぐべ きです。このような精神にこそ, 経済環境の変化に対す る企業の側からの創造的適応の主体的条件が求められる と思います。

中小企業の評価も時代と共飞変りつつ西ります。通説 によれば, 中小企業は大企業のくいものにされ，やがて は隇び去るとみていたのに対して, 中堅企業論の名の下 に新しい見解が提示されています。これからの産業界に とっては, 2 つの方向が考光られます。第 1 は, 少数の 大企業によって占められ, 人間踈外を深める管理社会化 です。第 2 は, 勤労者の自己管理（管理するものとされ るものの一体化）による産業民主化の徹底です。自然の 成り行きに委せれば, 第一の方向に進む可能性が強いで しょらがわれわれが好むならば第 2 の方向を選ぶこと ができるといら点に留意して欲しいと思います。後者を とるばあい, その実現は大企業よりも中小企業の方が容 易です。従来の物財中心の工業化社会につづく知識産業 社会では, 企業の成長力は, そこで働く人々の創造性発 揮いかんにかかっています。また, 昭和 30 年代の売手 市場は, 40 年代には買手市場に転換し, 企業にとって は需要創造または市場開発が中心課題となりました。こ のような経営環境の下では, 企業は在来品のコスト低下 をはかるよりは, 付加価值を高めうるような新商品を売 出すことによって創業者利潤を追求する傾向がみられま す。以上の諸点から中小企業の新たな存在理由が見出さ れるわけです。

すでに清酒業界では, 中堅企業論的見地から課税移出 量 $1,000 \mathrm{k} l$ をるつ地方の中堅メーカーがこれに該当す るものとし, 中堅企業の成立基盤を急速整備するよう 政策当局に強く要望して招ります（辻論文, 本誌, Vol. 66 , No. 9)。

しょう油のばあい，5大メーカーは自律的成長力を持 つものとして除外するならば, 規模の点から年産 $180 \mathrm{k} l$ 以上が中堅企業を見出しうる区間とみなすことができま しょう。それ以下は生業的性格が強く現状維持的だから 除外します。味噌のばあいは, 同じ理由から年産 1 万卜 ン以上の上位 11 社を除き, 下限は年産 600 トン以上と いらことで, 中堅企業を見出しらる範团としてみまし た。もっと下限を引上げて，しょう油は $1,800 \mathrm{~kg}$, 味 噌は 1,875 トンとして探索範团を校れば効率が上るかも 知れません。いずれにせよ，規模による区間の設定は， 中堅企業の存立基盤を見出すための作業仮設にほかなり ません。味噌, しょう油の中堅企業の事例については散 発的にしか申し上げられませんので，他日を期すること にいたします。 